MINI REVIEW

\title{
The role of the novel adipocyte-derived hormone adiponectin in human disease
}

\author{
Juan J Díez and Pedro Iglesias ${ }^{1}$ \\ Department of Endocrinology, Hospital Ramón y Cajal, Madrid, Spain and ${ }^{1}$ Department of Endocrinology, Hospital General, Segovia, Spain \\ (Correspondence should be addressed to J J Díez, Travesía Téllez 8, 4R, 28007 Madrid, Spain; Email: mibarsd@infomed.es)
}

\begin{abstract}
Adiponectin, also called GBP-28, apM1, AdipoQ and Acrp30, is a novel adipose tissue-specific protein that has structural homology to collagen VIII and X and complement factor C1q, and that circulates in human plasma at high levels. It is one of the physiologically active polypeptides secreted by adipose tissue, whose multiple functions have started to be understood in the last few years.

A reduction in adiponectin expression is associated with insulin resistance in some animal models. Administration of adiponectin has been accompanied by a reduction in plasma glucose and an increase in insulin sensitivity. In addition, thiazolidinediones, drugs that enhance insulin sensitivity through stimulation of the peroxisome proliferator-activated receptor- $\gamma$, increase plasma adiponectin and mRNA levels in mice. On the other hand, this adipocyte protein seems to play a protective role in experimental models of vascular injury. In humans, adiponectin levels are inversely related to the degree of adiposity and positively associated with insulin sensitivity both in healthy subjects and in diabetic patients. Plasma adiponectin levels have been reported to be decreased in some insulin-resistant states, such as obesity and type 2 diabetes mellitus, and also in patients with coronary artery disease. On the contrary, chronic renal failure, type 1 diabetes and anorexia nervosa are associated with increased plasma adiponectin levels. Concentrations of plasma adiponectin have been shown to correlate negatively with glucose, insulin, triglyceride levels and body mass index, and positively with high-density lipoprotein-cholesterol levels and insulin-stimulated glucose disposal. Weight loss and therapy with thiazolidinediones increased endogenous adiponectin production in humans.

Adiponectin increases insulin sensitivity by increasing tissue fat oxidation, resulting in reduced circulating fatty acid levels and reduced intracellular triglyceride contents in liver and muscle. This protein also suppresses the expression of adhesion molecules in vascular endothelial cells and cytokine production from macrophages, thus inhibiting the inflammatory processes that occur during the early phases of atherosclerosis. In view of these data, it is possible that hypoadiponectinemia may play a role in the development of atherosclerotic vascular disease.

In summary, the ability of adiponectin to increase insulin sensitivity in conjunction with its antiinflammatory and anti-atherogenic properties have made this novel adipocytokine a promising therapeutic tool for the future, with potential applications in states associated with low plasma adiponectin levels.
\end{abstract}

European Journal of Endocrinology 148 293-300

\section{Introduction}

Adipose tissue is currently considered as a hormonally active system in the control of metabolism and not only as a store of excess energy (1). The term 'adipocytokines' has been coined to refer to a series of adipocyte-derived biologically active molecules which may influence the function as well as the structural integrity of other tissues. Some examples of these substances are leptin, acylation-stimulating protein (ASP), tumor necrosis factor- $\alpha$ (TNF- $\alpha$ ), plasminogen activator inhibitor-1 (PAI-1) and interleukin-6. It is also likely that some of these adipocytokines mediate the systemic effects of obesity on health. As a matter of fact, leptin is considered to be a fundamental signal of satiety to the brain and has a variety of actions, ranging from interference with sympathetic activity to hematopoiesis and reproductive function (2). ASP increases triglyceride synthesis by increasing adipocyte glucose uptake, activating diacylglycerol acyltransferase, and inhibiting hormone-sensitive lipase $(3,4)$. Overproduction of TNF- $\alpha$ by adipose tissue is involved in insulin resistance in obesity (5), and PAI-1 is a well-recognized causative factor for vascular thrombosis (6). More recently, 
resistin has been identified as a novel adipose-specific cysteine-rich protein with a capacity to impair insulin sensitivity and glucose tolerance in murine models (7).

Adiponectin is a recently discovered adipocytokine, also referred to as gelatin-binding protein-28 $(8,9)$. It is a 244 amino acid protein, the product of the apM1 gene, which is specifically and highly expressed in human adipose cells (8). This cytokine is a collagenlike protein that belongs to the soluble defense collagen superfamily and has structural homology with collagen VIII and X and complement factor C1q $(8,10-13)$. The protein possesses a signal sequence at the $\mathrm{NH}_{2}$-terminal end followed by a short hypervariable region with no homology among different species, a collagen-like domain, and a Clq-like globular domain at the COOH-terminal end $(11,14)$. Adiponectin is abundant in human plasma, with concentrations ranging from 5 to $30 \mu \mathrm{g} / \mathrm{ml}$, thus accounting for approximately $0.01 \%$ of total plasma protein (15). This concentration is three orders of magnitude higher than concentrations of most other hormones. A mouse homolog, whose expression was limited to the adipose tissue, was identified in two independent laboratories and designated AdipoQ (11) and adipocyte complementrelated protein of $30 \mathrm{kDa}$ (10) respectively.

A physiological role for adiponectin has not been fully established. However, experimental data suggest that adiponectin may have anti-atherogenic $(16,17)$ and anti-inflammatory (18) properties. Very recent data have shown that adiponectin-deficient mice have severe neointimal thickening and increased proliferation of vascular smooth muscle cells in mechanically injured arteries $(19,20)$. Furthermore, reduced adipose tissue apM1 gene expression and reduced plasma levels of adiponectin have been implicated in the pathogenesis of obesity and type 2 diabetes mellitus (21). Mice lacking adiponectin have been found to display insulin resistance in some conditions $(20,22)$. In this brief review we analyze the pathophysiological role of adiponectin in human disease and suggest some potential therapeutic uses of this novel adiposespecific protein.

\section{Studies in experimental animals}

Recent data have shown that a reduction in adiponectin expression is associated with obesity and insulin resistance in some animal models. Hu et al. (11) found that levels of transcripts for adiponectin in white adipose tissue were lower in $o b / o b$ mice than in wild-type mice, and showed that, in $o b / o b$ mice, the steady-state mRNA of adiponectin was down-regulated (11). It is possible that the expression of adiponectin is activated during adipogenesis, but a feedback inhibition on its production may be imposed in the development of obesity. In fact, the recent demonstration by microarray that the expression of adipogenic genes was suppressed in the development of obesity and diabetes mellitus in mice does argue for the existence of a feedback inhibitory pathway (23). Interestingly, a prospective study in rhesus monkeys showed that the decrease in plasma adiponectin levels paralleled the development of insulin resistance and diabetes (24). These observations suggest that low plasma adiponectin may contribute to the pathogenesis of insulin resistance and diabetes mellitus in animals.

Pharmacological studies have shown that administration of the globular region of adiponectin to mice is accompanied by weight loss in animals consuming a high-fat, high-sucrose diet, an effect that was associated with a reduction in plasma glucose, free fatty acids and triglycerides (25). Recombinant adiponectin reduces serum glucose in normal and diabetic rodents without stimulating insulin secretion (26). Adiponectin also markedly enhanced the ability of insulin to suppress glucose production by isolated hepatocytes. A recent study has shown that phosphorylation and activation of the $5^{\prime}$-AMP-activated protein kinase were stimulated with globular and full-length adiponectin in skeletal muscle and only with full-length adiponectin in the liver (27). This suggests that the glucose-lowering effects of adiponectin in vivo could be mediated via a direct muscle and hepatic action. However, data obtained in experiments involving the injection of fragments of bacterially expressed and purified adiponectin into rodents may not reflect the normal action of the native protein. It has recently been shown that endogenous adiponectin secreted by adipocytes is post-translationally modified into eight different isoforms and that six of the adiponectin isoforms are glycosylated at four lysine residues located in the collagenous domain of adiponectin (28). Functional analysis has revealed that full-length adiponectin produced by mammalian cells is more potent than bacterially generated adiponectin in enhancing insulin sensitivity, whereas this ability was attenuated when the glycosylated lysines were substituted with arginines (28).

Therefore, the relevance of the reported pharmacological effects to the physiological function of adiponectin is unclear. Recently mice lacking adiponectin have been generated by gene targeting, and experimental studies have clarified some aspects of adiponectin physiology. In fact, Kubota et al. (20) reported that heterozygous adiponectin-deficient (Adipo ${ }^{-1+}$ ) mice showed mild insulin resistance, while homozygous adiponectindeficient $\left(\right.$ Adipo $^{-/-}$) mice showed moderate insulin resistance with glucose intolerance despite body weight gain similar to that of wild-type mice. In another study, Maeda et al. (22) reported that adiponectin knock-out mice showed delayed clearance of free fatty acid from plasma and low levels of fatty acid transport protein 1 mRNA in muscle. There were no evidence of insulin resistance when adiponectin knock-out mice were fed on a regular chow. However, they found that 
feeding the Adipo $^{-/-}$mice a high-fat, high-sucrose diet for 2 weeks induced insulin resistance in these animals (22). On the contrary, experiments reported by Ma et al. (29) showed that plasma glucose and insulin levels and the results of i.p. glucose and insulin-tolerance tests were similar in both Adipo $^{-1-}$ and Adipo ${ }^{+/+}$mice. Hyperinsulinemic-euglycemic clamp analysis also showed similar glucose infusion rates to maintain similar glucose levels in both groups of mice. These findings suggest that adiponectin deficiency is implicated in the induction of insulin resistance in some circumstances and that this adipocyte-derived protein may play a protective role against insulin resistance.

On the other hand, it has been reported that insulin resistance in lipoatrophic mice was reversed by the combination of physiological doses of adiponectin and leptin, but only partially by either adiponectin or leptin alone (30). Therefore, a reduction of adiponectin seems to be implicated in the development of insulin resistance in murine models of both obesity and lipoatrophy. These data also suggest that replenishment of adiponectin might provide a novel treatment modality for insulin resistance and type 2 diabetes.

The peroxisome proliferator-activated receptor (PPAR) $-\gamma$ is a key transcriptional factor that induces adipocyte differentiation and controls many adipocyte genes (31). Upon activation, PPAR- $\gamma$ heterodimerizes with retinoic $X$ receptor, recruits specific cofactors, and binds to DNA response elements, thereby stimulating the transcription of target genes. PPAR- $\gamma$ is not only a main regulator of adipocyte differentiation but also an insulin sensitizer in vivo. Because it is highly abundant in adipose tissue, it is thought that the effects of PPAR $-\gamma$ in adipose tissue are crucial in explaining its role in insulin sensitization, but recent studies have highlighted the contribution of other tissues (32). Initial studies showed that mRNA of adiponectin in differentiated 3T3-L1 adipocytes was increased by administration of rosiglitazone, a synthetic PPAR- $\gamma$ agonist, for $24 \mathrm{~h} \mathrm{(33).} \mathrm{More} \mathrm{recently,} \mathrm{was} \mathrm{reported} \mathrm{that} \mathrm{adipo-}$ nectin mRNA expression was normalized or increased by thiazolidinediones in the adipose tissues of obese mice (34). In cultured 3T3-L1 adipocytes, incubation with troglitazone enhanced adiponectin mRNA expression and adiponectin secretion into the medium in a dose- and time-dependent fashion. These effects were also produced by two other thiazolidinediones (pioglitazone and rosiglitazone), but not by a synthetic PPAR- $\alpha$ ligand (34). Thiazolidinediones also enhanced the adiponectin promoter activity. On the contrary, TNF- $\alpha$ reduced the expression of adiponectin in adipocytes by suppressing its promoter activity, and thiazolidinediones restored this inhibitory effect by TNF- $\alpha$. Recent studies have also shown that plasma levels of adiponectin are also affected by PPAR- $\gamma$ agonist treatment in both lean and obese mice $(34,35)$. Data from Combs et al. (35) indicate that in $d b / d b$ mice chronic treatment with PPAR- $\gamma$ agonists induced a significant increase in plasma adiponectin levels. Similar effects were noted in a non-genetic type 2 diabetes model (fat-fed and low-dose streptozotocin-treated mice). In contrast, treatment of mice $(d b / d b$ or fat-fed) with metformin or a PPAR- $\alpha$ agonist did not affect plasma adiponectin levels (35).

Consequently, it seems that adiponectin is downregulated in obesity and insulin resistance, and that an increase in adiponectin may reverse insulin resistance in mice. Some experimental data suggest that elevated levels of catecholamines, due to sympathetic nervous system hyperactivity, play a part in the development of insulin resistance. Treatment with isoproterenol reduced adiponectin mRNA levels in a dose-dependent manner in 3T3-L1 adipocytes. The inhibitory effect of isoproterenol was almost completely reversed by pretreatment of adipocytes with propranolol, a $\beta$-adrenergic antagonist, and the protein kinase A inhibitor H-89. However, isoproterenol effects could be mimicked by stimulation of $G(S)$-proteins with cholera toxin and adenylate cyclase with forskolin (36). Moreover, $\beta$-adrenergic agonists and cAMP exerted an inhibitory effect on adiponectin gene expression and adiponectin secretion in cultured mouse explants from visceral and subcutaneous adipose tissue and on human visceral adipose tissue (37). Administration of a $\beta(3)$-agonist to mice also reduced adiponectin mRNA in both visceral and subcutaneous adipose tissue, and adiponectin levels in plasma (37). These results suggest that the expression of adiponectin gene is strongly suppressed by $\beta$-adrenergic agonists.

\section{Studies in humans}

There seems to be a clear relationship between adiponectin and fat mass in humans. However, in contrast to leptin, adiponectin levels are significantly reduced among obese subjects in comparison with lean control subjects. Arita et al. (15) showed that mean plasma adiponectin levels were $3.7 \mu \mathrm{g} / \mathrm{ml}$ in a group of obese patients, whereas in non-obese subjects these values reached a mean of $8.9 \mu \mathrm{g} / \mathrm{ml}$. In a recent longitudinal study, plasma adiponectin concentrations decreased with increasing adiposity in a group of children evaluated at 5 and 10 years of age (38). Adiponectin is the only adipose-specific protein known to date that is negatively regulated in obesity. In a group of normalweight and obese women plasma adiponectin was negatively correlated not only with body mass index and body fat mass, but also with serum leptin concentration, fasting insulin and calculated insulin resistance (39). Another study, performed in 967 Japanese subjects with normal weight, has shown that plasma adiponectin is negatively correlated with body mass index, systolic and diastolic blood pressure, fasting plasma glucose, insulin, insulin resistance, total and low-density lipoprotein-cholesterol, triglycerides and uric acid, 
and positively correlated with high-density lipoprotein (HDL)-cholesterol (40).

Like plasma leptin levels, adiponectin concentrations seem to be gender-dependent, being higher among women than men (40-42). Furthermore, the limited number of studies reported so far have shown that plasma adiponectin levels are reduced not only among obese patients (15), but also among patients with some of the disease states frequently associated with obesity, such as type 2 diabetes mellitus (41) and coronary artery disease (16).

In fact, the study by Hotta et al. (41) showed that adiponectin levels in patients with type 2 diabetes mellitus were lower than in non-diabetic patients, and were particularly low in subjects with coronary artery disease. The presence of microangiopathy did not affect the plasma adiponectin levels in diabetic patients. In this study, plasma adiponectin concentrations were shown to correlate negatively with plasma glucose, insulin and triglyceride levels and body mass index, but positively with plasma levels of HDL-cholesterol (41). In a recent study performed in 23 Caucasians and 121 Pima Indians, plasma adiponectin concentrations were shown to be negatively correlated with percent body fat, waist-to-thigh ratio, and fasting insulin level and $2 \mathrm{~h}$ glucose concentration. In both ethnic groups, adiponectin levels were also demonstrated to correlate positively with insulin-stimulated glucose disposal measured by a hyperinsulinemic-euglycemic clamp. Multivariate analysis demonstrated that hypoadiponectinemia was more intensively related to the degree of insulin resistance and hyperinsulinemia than to the degree of adiposity or glucose intolerance (43). These results suggest that insulin resistance and hyperinsulinemia might be major determinants of the hypoadiponectinemia in obesity and type 2 diabetes (43). A case-control study in 140 Pima Indians has also shown that subjects with low concentrations of adiponectin are more likely to develop type 2 diabetes than those with high concentrations (44). In addition, firstdegree relatives of type 2 diabetic patients have reduced adiponectin mRNA expression in adipose tissue compared with controls, although they have normal levels of circulating adiponectin (45), thus indicating that there is a dysregulation of adiponectin gene expression in these subjects.

Recent genome-wide scans have mapped a diabetessusceptibility locus to chromosome $3 \mathrm{q} 27$, where the adiponectin gene (apM1) is located $(12,46,47)$. Evidence of an association between type 2 diabetes and single nucleotide polymorphisms at positions 45 and $276(48,49)$, and in the proximal promoter and exon 3 (50) of the adiponectin gene has been reported. Some missense mutations in the globular domain have been also associated with low adiponectin levels and type 2 diabetes (51). However, the regulation of adiponectin gene expression is presently unknown.
The relationships between adiponectin and serum lipid concentrations have recently been studied. In a large number of non-diabetic women with dyslipidemia, Matsubara et al. (52) have shown that plasma adiponectin is negatively correlated with serum triglyceride, atherogenic index, apo B or apo E, and positively correlated with serum HDL-cholesterol or apo A-I levels. These data suggest that low adiponectin concentrations are associated with some of the well-known risk factors for atherosclerosis, such as low HDL-cholesterol levels or hypertriglyceridemia. A relationship between hypoadiponectinemia and the metabolic syndrome seems likely (53).

Recent evidence also suggests that weight loss induces an increase in adiponectin levels in obesity. In a group of 22 obese patients, who were treated by gastric partition surgery, a $46 \%$ increase in mean plasma adiponectin level was accompanied by a $21 \%$ reduction in mean body mass index (54). Changes in plasma adiponectin were related to changes in body mass index, waist and hip circumferences, and steady-state plasma glucose levels. These data suggest the existence of a negative feedback mechanism between adipose mass and the production of adiponectin in humans.

Human studies have replicated the finding in animal models that thiazolidinedione treatment enhances endogenous adiponectin production. In fact, in a group of mildly overweight subjects with glucose intolerance the administration of troglitazone for 12 weeks significantly increased the plasma adiponectin concentration in a dose-dependent way (34). Troglitazone treatment for 3 months was also accompanied by an increase in adiponectin levels in a group of diabetic patients and in lean and obese non-diabetic subjects (55). In a recent randomized double-blind placebocontrolled trial performed in 64 type 2 diabetic patients, rosiglitazone therapy for 6 months was accompanied by a more than 2 -fold increase in plasma adiponectin levels (56). Similar results have been reported with pioglitazone (57). Furthermore, circulating adiponectin levels were found to be suppressed 5-fold in patients with severe insulin resistance in association with dominant-negative PPAR- $\gamma$ mutations, thus suggesting that adiponectin may be a biomarker of in vivo PPAR- $\gamma$ activation (35). Plasma adiponectin levels have also been found to be significantly lower in Japanese subjects with the Pro12Ala polymorphism of the PPAR- $\gamma 2$ gene, although body mass index, plasma glucose, serum lipids and insulin resistance index were not different between subjects with and without this polymorphism (58).

There is only one report on serum concentrations of adiponectin in patients with chronic renal failure (59). In this study, performed in 227 hemodialysis patients, plasma adiponectin levels were 2.5 times higher among dialysis patients than among healthy subjects, and they were higher among women than among men. Renal metabolism of adiponectin has been 
barely investigated, although changes in clearance rates and other unknown factors may account for the elevated plasma levels found in patients with endstage renal disease. Follow-up of uremic patients showed that plasma adiponectin levels were lower among patients who experienced new cardiovascular events than among event-free patients (59), suggesting that adiponectin might act as a protective factor against atherosclerosis in these patients.

Plasma adiponectin concentrations have been found to be significantly elevated in a group of 46 type 1 diabetic patients in relation to healthy controls (60). Insulin replacement therapy did not affect adiponectin levels in a subgroup of seven patients. A preliminary report also showed that adiponectin levels were moderately elevated in 26 female patients with anorexia nervosa (61). However, further investigations involving a larger number of patients are required to confirm these results.

The mechanisms responsible for the control of the synthesis of adiponectin have not been determined so far. The only hormone implicated in the regulation of adiponectin expression has been insulin (10). A recent study has shown that treatment of 3T3-L1 adipocytes with insulin suppresses adiponectin gene expression and that insulin reduces the level of adiponectin mRNA in a dose- and time-dependent fashion (62). During a hyperinsulinemic-euglycemic glucose clamp, adiponectin levels were suppressed below basal levels in both diabetic and non-diabetic subjects (55). However, an improvement in insulin sensitivity by exercise training with no loss of body mass did not modify plasma adiponectin concentrations (63). Furthermore, the mechanisms implicated in the decreased adiponectin concentration in insulin resistance also remain obscure. TNF- $\alpha$ is one of the candidate molecules responsible for causing insulin resistance. The expression and secretion of adiponectin from adipocytes are significantly reduced by $\mathrm{TNF}-\alpha(62,64)$. Therefore, increased TNF- $\alpha$ might be partially responsible for the decreased adiponectin production in obesity. It is also possible, although it has not been demonstrated, that adiponectin itself may increase insulin sensitivity through an inhibition of both the production and action of TNF- $\alpha$. It has also been hypothesized that adiponectin and TNF- $\alpha$ may antagonize each other or perform opposite functions locally in adipose tissue or in the arterial wall (34).

$\beta$-adrenergic agonists $(37,65)$, activators of adenylate cyclase $(36)$ and glucocorticoids $(62,66)$ are also reported to inhibit adiponectin gene expression and secretion, suggesting that decreased adiponectin production could play a role in catecholamine- or glucocorticoid-induced insulin resistance. Treatment with testosterone in both sham-operated and castrated mice was accompanied by a reduction in plasma adiponectin, and, in 3T3-L1 adipocytes, testosterone also reduced adiponectin secretion, thus indicating that androgen-induced hypoadiponectinemia might be related to the high risks of insulin resistance and atherosclerosis in men (42). Taken together, these data support the concept that adiponectin gene expression is reversibly down-regulated by insulin, TNF- $\alpha$ and other substances.

\section{Mechanism of action of adiponectin}

The site and mechanism of adiponectin actions on glucose metabolism remain unknown and receptors for adiponectin have not been identified to date. The pharmacological effect of adiponectin in reducing insulin resistance is related to a decrease in plasma fatty acid levels and in triglyceride content in muscle and liver in obese mice $(25,30)$. These observations may be due to enhanced expression of genes involved in $\beta$-oxidation and energy dissipation, such as acyl-CoA oxidase and uncoupling protein-2 (30). Moreover, insulin-stimulated tyrosine phosphorylation of signaling molecules, including insulin receptor and insulin receptor substrate-1 in skeletal muscle, was also enhanced by adiponectin (30). In addition to its activation of the 5'-AMP-activated protein kinase, adiponectin also stimulated phosphorylation of acetyl-CoA carboxylase, fatty acid oxidation, glucose uptake and lactate production in myocytes, and phosphorylation of acetyl-CoA carboxylase and reduction of molecules involved in gluconeogenesis in the liver (27). In humans a role for physiological concentrations of fasting plasma adiponectin in the regulation of skeletal muscle insulin receptor tyrosine phosphorylation has recently demonstrated (67).

Experimental evidence suggests that adiponectin might play a protective role against atherosclerosis. Low plasma adiponectin levels have been reported in coronary artery disease, as well as associated with some risk factors of cardiovascular disease such as male sex, high blood pressure, obesity and type 2 diabetes mellitus $(15,16,59,68)$. Furthermore, the deficiency of plasma adiponectin is associated with 2-fold more neointimal formation in response to external vascular cuff injury in mice (20). During the early phase of atherosclerosis, the monocyte macrophages secrete various cytokines and growth factors that promote smooth muscle cell proliferation. Adiponectin has shown to reduce the secretion of TNF- $\alpha$ from monocyte macrophages, and also to attenuate the biological effects induced by TNF- $\alpha$. In fact, this protein suppresses the secretion of TNF- $\alpha$ from macrophages and foam cell formation (69). Experiments with adiponectin knock-out mice have demonstrated that mice lacking this protein show high levels of TNF- $\alpha$ mRNA in adipose tissue and high plasma TNF- $\alpha$ concentrations, and viral-mediated adiponectin expression in these knock-out mice reverses the increase of adipose TNF- $\alpha$ mRNA (22). In cultured 
human monocyte-derived macrophages, it has been also demonstrated that adiponectin reduced cholesterol ester accumulation and class A scavenger receptor gene expression (69). In cultured smooth muscle cells, adiponectin attenuated DNA synthesis induced by several growths factors, such as platelet-derived growth factor, heparin-binding epidermal growth factor-like growth factor (HB-EGF), basic fibroblastic growth factor and epidermal growth factor $(19,70)$. Cell proliferation and migration induced by HB-EGF was also diminished by adiponectin (19).

Adiponectin also inhibits the expression of intracellular adhesion molecule-1, endothelial cell adhesion molecule-1 and E-selectin in endothelial cells in vitro, and prevents the attachment of monocytes in TNF- $\alpha$-stimulated human aortic endothelial cells (16, 17, 69). This adipocyte-derived protein has recently been reported to have an inhibitory effect on the proliferation of myelomonocytic progenitors as well as on phagocytic activity and TNF- $\alpha$ production by macrophages (18). In addition, it may induce apoptosis in myelomonogenic cell lines (18). It has been also suggested that adiponectin modulates nuclear factor- $\mathrm{\kappa B}$ signaling through a cAMP-dependent pathway (17). Therefore, this cytokine seems to act as an endogenous regulator of endothelial cells in response to inflammatory stimuli (16). Taken together, these data suggest that this adipocyte-derived cytokine may exert anti-inflammatory and anti-atherogenic effects, specially in endothelial cells and macrophages, and therefore it seems to play a protective role in experimental models of vascular injury as well as in the early events in the atherosclerotic process.

\section{Potential therapeutic applications}

Adiponectin is the most abundant adipose-specific protein and is exclusively expressed and secreted from adipose tissue. Evidence reported so far suggests that adiponectin possesses antihyperglycemic, anti-atherogenic and anti-inflammatory properties. Increased serum adiponectin levels are associated with increased insulin sensitivity and glucose tolerance (71). Therefore, it can be speculated that adiponectin - or drugs that stimulate adiponectin secretion or action might play a role in the therapeutic armamentarium against disease states associated with insulin resistance, mainly type 2 diabetes mellitus and obesity (30). Low levels of adiponectin have also been implicated in the severe insulin resistance that accompanies lipoatrophy both in animal models (30) and in humans (72). Therapy with adiponectin may also play a role in reversing insulin resistance in lipodystrophic disorders.

The anti-inflammatory effects of adiponectin indicate that it is an interesting protective factor for atherosclerosis development, especially in those clinical situations associated with low plasma levels of adiponectin. It is conceivable that the use of recombinant adiponectin may become beneficial in the prevention of cardiovascular disease in selected patients. The recent finding that adiponectin deficiency aggravates neointimal thickening, and that supplementation with adiponectin attenuates neointimal thickening in mechanically injured arteries, suggests that increasing plasma adiponectin might be useful in preventing vascular restenosis after vascular intervention (19). Testing these hypotheses is a challenge for future clinical research. Further investigations in patients with the above-mentioned states and other hypoadiponectinemic situations are required to clarify these aspects of the potential therapeutic applications of this fascinating adipocytokine.

\section{References}

1 Trayhurn P \& Beattie JH. Physiological role of adipose tissue: white adipose tissue as an endocrine and secretory organ. Proceedings of the Nutrition Society $200160329-339$.

2 Mantzoros CS. The role of leptin in human obesity and disease: a review of current evidence. Annals of Internal Medicine 1999130 651-657.

3 Cianflone K, Maslowska M \& Sniderman AD. Acylation stimulating protein (ASP), and adipocyte autocrine: new directions. Seminars in Cell Development and Biology $19991031-41$.

4 Murray I, Sniderman AD, Havel PJ \& Cianflone K. Acylation stimulating protein (ASP) deficiency alters postprandial and adipose tissue metabolism in male mice. Journal of Biological Chemistry $199927436219-36225$.

5 Hotamisligil GS, Shargill NS \& Spiegelman BM. Adipose expression of tumor necrosis factor-alpha: direct role in obesitylinked insulin resistance. Science 1993259 87-91.

6 Auwerx J, Bouillon R, Collen D \& Geboers J. Tissue-type plasminogen activator antigen and plasminogen activator inhibitor in diabetes mellitus. Arteriosclerosis $1988 \mathbf{8} 68-72$.

7 Steppan CM, Bailey ST, Bhat S, Brown EJ, Banerjee RR, Wright $\mathrm{CM}$ et al. The hormone resistin links obesity to diabetes. Nature $2001409307-312$.

8 Maeda K, Okubo K, Shimomura I, Funahashi T, Matsuzawa Y \& Matsubara K. cDNA cloning and expression of a novel adipose specific collagen-like factor, apM1 (adipose most abundant gene transcript 1). Biochemical and Biophysical Research Communications $1996221286-289$.

9 Nakano Y, Tobe T, Choi-Miura NH, Mazda T \& Tomita T. Isolation and characterization of GBP28, a novel gelatin-binding protein purified from human plasma. Journal of Biochemistry $1996 \mathbf{1 2 0}$ 803-812.

10 Scherer PE, Williams S, Fogliano M, Baldini G \& Lodish HF. A novel serum protein similar to $\mathrm{C} 1 \mathrm{q}$, produced exclusively in adipocytes. Journal of Biological Chemistry $1995 \quad \mathbf{2 7 0}$ 26746-26749.

$11 \mathrm{Hu}$ E, Liang P \& Spiegelman BM. AdipoQ is a novel adipocytespecific gene dysregulated in obesity. Journal of Biological Chemistry 1996271 10697-10703.

12 Takahashi M, Arita Y, Yamagata K, Matsukawa Y, Okutomi K, Horie $\mathrm{M}$ et al. Genomic structure and mutations in adiposespecific gene, adiponectin. International Journal of Obesity 2000 $24861-868$.

13 Kishore U \& Reid KB. C1q: structure, function, and receptors. Immunopharmacology $2000 \mathbf{4 9} 159-170$.

14 Shapiro L \& Scherer PE. The crystal structure of a complement-1q family protein suggests an evolutionary link to tumor necrosis factor. Current Biology $1998 \mathbf{8} 335-338$. 
15 Arita Y, Kihara S, Ouchi N, Takahashi M, Maeda K, Miyagawa J et al. Paradoxical decrease of an adipocyte specific protein, adiponectin, in obesity. Biochemical and Biophysical Research Communications 1999257 79-83.

16 Ouchi N, Kihara S, Arita Y, Maeda K, Kuriyama H, Okamoto Y et al. Novel modulator for endothelial adhesion molecules: adipocyte-derived plasma protein adiponectin. Circulation 1999100 2473-2476.

17 Ouchi N, Kihara S, Arita Y, Okamoto Y, Maeda K, Kuriyama H et al. Adiponectin, adipocyte-derived plasma protein, inhibits endothelial NF- $\mathrm{B}$ signaling through cAMP-dependent pathway. Circulation 2000102 1296-1301.

18 Yokota T, Oritani K, Takahashi I, Ishikawa J, Matsuyama A, Ouchi $\mathrm{N}$ et al. Adiponectin, a new member of the family of soluble defense collagens, negatively regulates the growth of myelomonocytic progenitors and the functions of macrophages. Blood 2000 $961723-1732$.

19 Matsuda M, Shimomura I, Sata M, Arita Y, Nishida M, Maeda N et al. Role of adiponectin in preventing vascular stenosis. The missing link of adipo-vascular axis. Journal of Biological Chemistry $200227737487-37491$.

20 Kubota N, Terauchi Y, Yamauchi T, Kubota T, Moroi M, Matsui J et al. Disruption of adiponectin causes insulin resistance and neointimal formation. Journal of Biological Chemistry $2002 \mathbf{2 7 7}$ 25863-25866

21 Statnick MA, Beavers LS, Conner LJ, Corominola H, Johnson D, Hammond CD et al. Decreased expression of apM1 in omental and subcutaneous adipose tissue of humans with type 2 diabetes. International Journal of Reproduction and Diabetes Research $2000 \mathbf{1}$ $51-58$.

22 Maeda N, Shimomura I, Kishida K, Nishizawa H, Matsuda M, Nagaretani $\mathrm{H}$ et al. Diet-induced insulin resistance in mice lacking adiponectin/ACRP30. Nature Medicine 20028 731-737.

23 Nadler ST, Stoehr JP, Schueler KL, Tanimoto G, Yandell BS \& Attie $\mathrm{AD}$. The expression of adipogenic genes is decreased in obesity and diabetes mellitus. PNAS $20019711371-11376$

24 Hotta K, Funahashi T, Bodkin NL, Ortmeyer HK, Arita Y, Hansen $\mathrm{BC}$ et al. Circulating concentrations of the adipocyte protein adiponectin are decreased in parallel with reduced insulin sensitivity during the progression to type 2 diabetes in rhesus monkeys. Diabetes 200150 1126-1133.

25 Fruebis J, Tsao TS, Javorschi S, Ebbets-Reed D, Erickson MR, Yen FT et al. Proteolitic cleavage product of $30-\mathrm{kDa}$ adipocyte complement-related protein increases fatty acid oxidation in muscle and causes weight loss in mice. PNAS 200198 2005-2010.

26 Berg AH, Combs TP, Du X, Brownlee M \& Scherer P. The adipocyte-secreted protein ACRP30 enhances hepatic insulin action. Nature Medicine 20017 947-953.

27 Yamauchi T, Kamon J, Minokoshi Y, Ito Y, Waki H, Uchida S et al. Adiponectin stimulates glucose utilization and fatty-acid oxidation by activating AMP-activated protein kinase. Nature Medicine 20028 1288-1295.

28 Wang Y, Xu A, Knight C, Xu LY \& Cooper GJ. Hydroxylation and glycosylation of the four conserved lysine residues in the collagenous domain of adiponectin. Potential role in the modulation of its insulin-sensitizing activity. Journal of Biological Chemistry $200227719521-19529$.

29 Ma K, Cabrero A, Saha PK, Kojima H, Li L, Chang BH et al. Increased $\beta$-oxidation but no insulin resistance or glucose intolerance in mice lacking adiponectin. Journal of Biological Chemistry $200227734658-34661$.

30 Yamauchi T, Kamon J, Waki H, Terauchi Y, Kubota N, Hara K et al. The fat-derived hormone adiponectin reverses insulin resistance associated with both lipoatrophy and obesity. Nature Medicine $20017941-946$.

31 Rocchi S \& Auwerx J. Peroxisome proliferator-activated receptorgamma: a versatile metabolic regulator. Annals of Medicine 1999 $31342-351$.
32 Picard F \& Auwerx J. PPAR $\gamma$ and glucose homeostasis. Annual Review of Nutrition 200222 167-197.

33 Lin WS, Chang HM, Tai TY \& Chuang LM. Effect of thiazolidinedione on gene expression in NIH3T3-L1 adipocytes. Diabetes 199948 (Suppl 1) A217.

34 Maeda N, Takahashi M, Funahashi T, Kihara S, Nishizawa H, Kishio K et al. PPAR $\gamma$ ligands increase expression and plasma concentrations of adiponectin, an adipose-derived protein. Diabetes 200150 2094-2099.

35 Combs TP, Wagner JA, Berger J, Doebber T, Wang WJ, Zhang BB et al. Induction of adipocyte complement-related protein of 30 kilodaltons by PPARgamma agonists: a potential mechanism of insulin sensitization. Endocrinology 2002143 998-1007.

36 Fasshauer M, Klein J, Neumann S, Eszlinger M \& Paschke R. Adiponectin gene expression is inhibited by beta-adrenergic stimulation via protein kinase A in 3T3-L1 adipocytes. FEBS Letters 2001507 142-146.

37 Delporte ML, Funahashi T, Takahashi M, Matsuzawa Y \& Brichard SM. Pre- and post-translational negative effect of betaadrenoceptor agonists on adiponectin secretion: in vitro and in vivo studies. Biochemical Journal $2002367677-685$.

38 Stefan N, Bunt JC, Salbe AD, Funahashi T, Matsuzawa Y \& Tataranni PA. Plasma adiponectin concentrations in children: relationships with obesity and insulinemia. Journal of Clinical Endocrinology and Metabolism 200287 4652-4656.

39 Matsubara M, Maruoka S \& Katayose S. Inverse relationship between plasma adiponectin and leptin concentrations in normal-weight and obese women. European Journal of Endocrinology $2002147173-180$.

40 Yamamoto $\mathrm{Y}$, Hirose H, Saito I, Tomita M, Taniyama M, Matsubara K et al. Correlation of the adipocyte-derived protein adiponectin with insulin resistance index and serum high-density lipoprotein-cholesterol, independent of body mass index, in the Japanese population. Clinical Sciences 2002103 137-142.

41 Hotta K, Funahashi T, Arita Y, Takahashi M, Matsuda M, Okamoto Y et al. Plasma concentrations of a novel adipose-specific protein, adiponectin, in type 2 diabetic patients. Arteriosclerosis and Thrombosis Vascular Biology 200020 1595-1599.

42 Nishizawa H, Shimomura I, Kishida K, Maeda N, Kuriyama H, Nagaretani $\mathrm{H}$ et al. Androgens decrease plasma adiponectin, an insulin-sensitizing adipocyte-derived protein. Diabetes 200251 2734-2741.

43 Weyer C, Funahashi T, Tanaka S, Hotta K, Matsuzawa Y, Pratley RE et al. Hypoadiponectinemia in obesity and type 2 diabetes: close association with insulin resistance and hyperinsulinemia. Journal of Clinical Endocrinology and Metabolism $2001 \mathbf{8 6}$ 1930-1935.

44 Lindsay RS, Funahashi T, Hanson RL, Matsuzawa Y, Tanaka S, Tataranni PA et al. Adiponectin and development of type 2 diabetes in the Pima Indian population. Lancet $2002 \mathbf{3 6 0}$ $57-58$.

45 Lihn AS, Ostergard T, Nyholm B, Pedersen SB, Richelsen B \& Schmitz O. Adiponectin mRNA expression in subcutaneous adipose tissue is reduced in first-degree relatives of type 2 diabetic patients. American Journal of Physiology. Endocrinology and Metabolism 2003284 E443-E448.

46 Kissebah AH, Sonnenberg GE, Myklebust J, Goldstein M, Broman $\mathrm{K}$, James RG et al. Quantitative trait loci on chromosomes 3 and 17 influence phenotypes of the metabolic syndrome. PNAS $20009714478-14483$.

47 Stumvoll M, Tschritter O, Fritsche A, Staiger H, Renn W, Weisser $\mathrm{M}$ et al. Association of the T-G polymorphism in adiponectin (exon 2) with obesity and insulin sensitivity: interaction with family history of type 2 diabetes. Diabetes $20025137-41$.

48 Hara K, Boutin P, Mori Y, Tobe K, Dina C, Yasuda K et al. Genetic variation in the gene encoding adiponectin is associated with an increased risk of type 2 diabetes in the Japanese population. Diabetes 200251 536-540.

49 Menzaghi C, Ercolino T, Di Paola R, Berg AH, Warram JH, Scherer PE et al. A haplotype at the adiponectin locus is associated 
with obesity and other features of the insulin resistance syndrome. Diabetes 200251 2306-2312.

50 Vasseur F, Helbecque N, Dina C, Lobbens S, Delannoy V, Gaget S et al. Single-nucleotide polymorphism haplotypes in the both proximal promoter and exon 3 of the APM1 gene modulate adipocyte-secreted adiponectin hormone levels and contribute to the genetic risk for type 2 diabetes in French Caucasians. Human and Molecular Genetics 200211 2607-2614.

51 Kondo H, Shimomura I, Matsukawa Y, Kumada M, Takahashi M, Matsuda $\mathrm{M}$ et al. Association of adiponectin mutation with type 2 diabetes. A candidate gene for the insulin resistance syndrome. Diabetes $2002512325-2328$.

52 Matsubara M, Maruoka S \& Katayose S. Decreased plasma adiponectin concentrations in women with dyslipidemia. Journal of Clinical Endocrinology and Metabolism 200287 2764-2769.

53 Matsuzawa Y, Funahashi T \& Nakamura T. Molecular mechanism of metabolic syndrome X: contribution of adipocytokines adipocyte-derived bioactive substances. Annals of the New York Academy of Sciences $1999 \mathbf{8 9 2} 146-154$.

54 Yang WS, Lee WJ, Funahashi T, Tanaka S, Matsuzawa Y, Chao CL et al. Weight reduction increases plasma levels of an adiposederived anti-inflammatory protein, adiponectin. Journal of Clinical Endocrinology and Metabolism 200186 3815-3819.

55 Yu JG, Javorschi S, Hevener AL, Kruszynska YT, Norman RA, Sinha M et al. The effect of thiazolidinedione on plasma adiponectin levels in normal, obese, and type 2 diabetic subjects. Diabetes $2002512968-2974$.

56 Yang WS, Jeng CY, Wu TJ, Tanaka S, Funahashi T, Matsuzawa Y et al. Synthetic peroxisome proliferator-activated receptor- $\gamma$ agonist, rosiglitazone, increases plasma levels of adiponectin in type 2 diabetic patients. Diabetes Care 200225 376-380.

57 Hirose H, Kawai T, Yamamoto Y, Taniyama M, Tomita M, Matsubara K et al. Effects of pioglitazone on metabolic parameters, body fat distribution, and serum adiponectin levels in Japanese male patients with type 2 diabetes. Metabolism $2002 \mathbf{5 1}$ 314-317.

58 Yamamoto Y, Hirose H, Miyashita K, Nishikai K, Saito I, Taniyama $\mathrm{M}$ et al. PPARgamma2 gene Pro12Ala polymorphism may influence serum level of an adipocyte-derived protein, adiponectin, in the Japanese population. Metabolism $2002 \mathbf{5 1}$ 1407-1409.

59 Zoccali C, Mallamaci F, Tripepi G, Benedetto FA, Cutrupi S, Parlongo $S$ et al. Adiponectin, metabolic risk factors, and cardiovascular events among patients with end-stage renal disease. Journal of the American Society of Nephrology 200213 134-141.

60 Imagawa A, Funahashi T, Nakamura T, Noriwaki M, Tanaka S, Hishizawa $\mathrm{H}$ et al. Elevated serum concentration of adiposederived factor, adiponectin, in patients with type 1 diabetes. Diabetes Care 200225 1665-1666.

61 Delporte ML, Lambert MJ, Hermans MP \& Brichard SM. Hyperadiponectinemia in anorexia nervosa. Diabetologia $2002 \mathbf{4 5}$ (Suppl 1) A223-A224.

62 Fasshauer M, Klein J, Neumann S, Eszlinger M \& Paschke R. Hormonal regulation of adiponectin gene expression in 3T3-L1 adipocytes. Biochemical and Biophysical Research Communications $20022901084-1089$.

63 Hulver MW, Zheng D, Tanner CJ, Houmard JA, Kraus WE, Slentz CA et al. Adiponectin is not altered with exercise training despite enhanced insulin action. American Journal of Physiology. Endocrinology and Metabolism 2002283 E861-E865.

64 Kappes A \& Loffler G. Influences of ionomycin, dibutyrylcycloAMP and tumour necrosis factor-alpha on intracellular amount and secretion of apM1 in differentiating primary human preadipocytes. Hormone and Metabolic Research 200032 548-554.

65 Zhang Y, Matheny M, Zolotukhin S, Tumer N \& Scarpace JP. Regulation of adiponectin and leptin gene expression in white and brown adipose tissue: influence of beta3-adrenergic agonists, retinoic acid, leptin and fasting. Biochimica et Biophysica Acta $20021584115-122$.

66 Halleux CM, Takahashi M, Delporte ML, Detry R, Funahashi T, Matsuzawa $Y$ et al. Secretion of adiponectin and regulation of apM1 gene expression in human visceral adipose tissue. Biochemical and Biophysical Research Communications $2001 \mathbf{2 8 8}$ 1102-1107.

67 Stefan N, Vozarova B, Funahashi T, Matsuzawa Y, Weyer C, Lindsay RS et al. Plasma adiponectin concentration is associated with skeletal muscle insulin receptor tyrosine phosphorylation, and low plasma concentration precedes a decrease in wholebody insulin sensitivity in humans. Diabetes $2002 \mathbf{5 1}$ 1884-1888.

68 Kazumi T, Kawaguchi A, Sakai K, Hirano T \& Yoshino G. Young men with high-normal blood pressure have lower serum adiponectin, smaller LDL size, and higher elevated heart rate than that with optimal blood pressure. Diabetes Care 200225 971-976.

69 Ouchi N, Kihara S, Arita Y, Nishida M, Matsuyama A, Okamoto Y et al. Adipocyte-derived plasma protein, adiponectin, suppresses lipid accumulation and class A scavenger receptor expression in human monocyte-derived macrophages. Circulation 2001103 1057-1063.

70 Arita Y, Kihara S, Ouchi N, Maeda K, Kuriyama H, Okamoto Y et al. Adipocyte-derived plasma protein adiponectin acts as a platelet-derived growth factor-BB-binding protein and regulates growth factor-induced common postreceptor signal in vascular smooth muscle cell. Circulation 2002105 2893-2898.

71 Yamauchi T, Oike Y, Kamon J, Waki H, Komeda K, Tsuchida A et al. Increased insulin sensitivity despite lipodystrophy in Crebbp heterozygous mice. Nature Genetics $200230221-226$.

72 Haque WA, Shimomura I, Matsuzawa Y \& Garg A. Serum adiponectin and leptin levels in patients with lipodystrophies. Journal of Clinical Endocrinology and Metabolism 200287 2395-2398.

Received 11 September 2002

Accepted 13 December 2002 